\title{
Impact of Air Pollution on Maize Production in the Sasolburg Area, South Africa
}

\author{
Phokele Maponya $^{1} \&$ Isaac T Rampedi $^{1}$ \\ ${ }^{1}$ Department of Geography, Environmental Management and Energy Studies, Faculty of Science, University of \\ Johannesburg, South Africa \\ Correspondence: Phokele Maponya, Department of Geography, Environmental Management and Energy Studies, \\ Faculty of Science, University of Johannesburg, South Africa. E-mail: phokelemaponya@gmail.com
}

Received: July 15, 2013 Accepted: August 19, 2013 Online Published: October 15, 2013

doi:10.5539/jas.v5n11p181 URL: http://dx.doi.org/10.5539/jas.v5n11p181

\begin{abstract}
Previous studies have shown that air pollution has an effect on maize production and can also influence yield. Since the pollution load at Sasolburg exceeds certain air quality standards, it is identified as a 'hot spot' and is therefore a perfect region to conduct studies regarding the impact of air pollution on maize production. The Northern Free State region is well known for its high maize production and residents of towns up to $50 \mathrm{~km}$ away from Sasolburg indicated that they can smell the fumes of the Sasolburg industries. This study included status of maize production over the past 5 years by visiting farmers every $25 \mathrm{~km}$ from Sasolburg, for $100 \mathrm{~km}$. Thus, 4 sampling points of $25 \mathrm{~km}$ intervals have been visited. Farmers were asked to fill in questionnaires and provide information related to air pollution and maize production. This was done in three different directions from Sasolburg. It is expected that maize yield near Sasolburg will be less than yield far from Sasolburg if pollution influence maize production. Average maize production by the Free State province as well as individual farmers, and other published and unpublished data which were used, concluded that maize production is in fact, influenced by the air pollution from Sasolburg, low income residents burning coal and other substances in the Sasolburg region. The research also indicated that new technology and techniques make it possible for farmers to maximize maize yield and still, year by year, increase the maize production on their farms. South Africa is able to adapt and work around the air pollution problem, but will enter a downwards maize production curve when the original pollution problem is not addressed. It is therefore recommended that the problem of air pollution in the Sasolburg region be solved, rather than adapting to the circumstances with new agricultural technologies. This study has contributed to maize production, air pollution influences on maize yield and farmer awareness in the Sasolburg region and nearby towns.
\end{abstract}

Keywords: air pollution, maize production, farmers, vaal triangle, sasolburg region, South Africa

\section{Introduction}

Global near-surface concentrations of ozone in the northern hemisphere have risen from between 10 and 20 parts per billion (ppb) at the beginning of the twentieth century to values between 20 and 40 ppb in recent times (Van Tienhoven et al., 2006). Ozone is the most prevalent and damaging air pollutant to which plants are exposed in many parts of Europe, North and Central America and the Far East. About 3 billion dollars' worth in losses have occurred in the USA due to the impacts of ozone on crops (Adams et al., 1988; Holmes, 1994). Ozone may affect crops in yield or quality reductions, as well as physical effects such as leaf spotting (Ollerenshaw et al., 1999; Fumagalli et al., 2001; Fuhrer \& Booker, 2003). Many researches of the impact of ozone and other pollutants have been conducted in Europe and North America, but very little research has been carried out in Africa.

South Africa is the biggest maize producers in Southern Africa and agriculture is important for export and subsistence (Holmes, 1994). Maize is a staple crop and is not particularly sensitive to ozone (Marenco et al., 1990). However, some studies show decreasing relative yield parameters with exposure to high ozone concentrations (Mulchi et al., 1995; Rudorff et al., 1996). Over rural parts in Southern Africa surface ozone varies between 20 and 40 ppb (Annegarn et al., 1996). At Cape point, South Africa, an unpolluted background measuring station, the ozone is $22 \mathrm{ppb}$. At Elandsfontein and Verkykerkop, located in an industrialised mining region, maximum hourly means of 76.8 and 110 ppb ozone were measured respectively (Kirkman et al., 2000). 
Maximum daily means over $40 \mathrm{ppb}$ were recorded at four out of five Highveld monitoring stations in 1994 (Rorich \& Galpin, 1998).

According Mdluli (2010) the primary air pollutants in South Africa are sulphur dioxide $\left(\mathrm{SO}_{2}\right)$, nitrogen dioxide $\left(\mathrm{NO}_{2}\right)$, ozone $\left(\mathrm{O}_{3}\right)$, lead $(\mathrm{Pb})$, benzene $\left(\mathrm{C}_{6} \mathrm{H}_{6}\right)$, carbon monoxide $(\mathrm{CO})$ and particulate matter with a diameter of 10 micrometers or less $\left(\mathrm{PM}_{10}\right)$, with the problem pollutants being $\mathrm{PM} 10$ and $\mathrm{SO}_{2}$. The Vaal triangle is considered as the industrial heartland of South Africa, which currently exceeds certain of the proposed ambient air quality standards. The Vaal Triangle Air-shed is classified as a priority area with Sasolburg being one of the 'hot-spots' (Figure 1). Different sources in the area contribute to the poor air quality and air pollution (Figure 2).

Previous studies done by Van Tienhoven et al. (2006); Adams et al. (1988) and Holmes (1994) included the effect of air pollution on maize production and offers sufficient motivation to conduct a study on a region in South Africa with perceived air pollution. One of the areas identified in South Africa with dangerously high pollution levels is Sasolburg. Studies conducted by the Department of Environmental Affairs (2010) indicated the possibility of pollution in areas surrounding Sasolburg and according to Figure 1; Sasolburg can be regarded as one of South Africa's highest polluted regions.

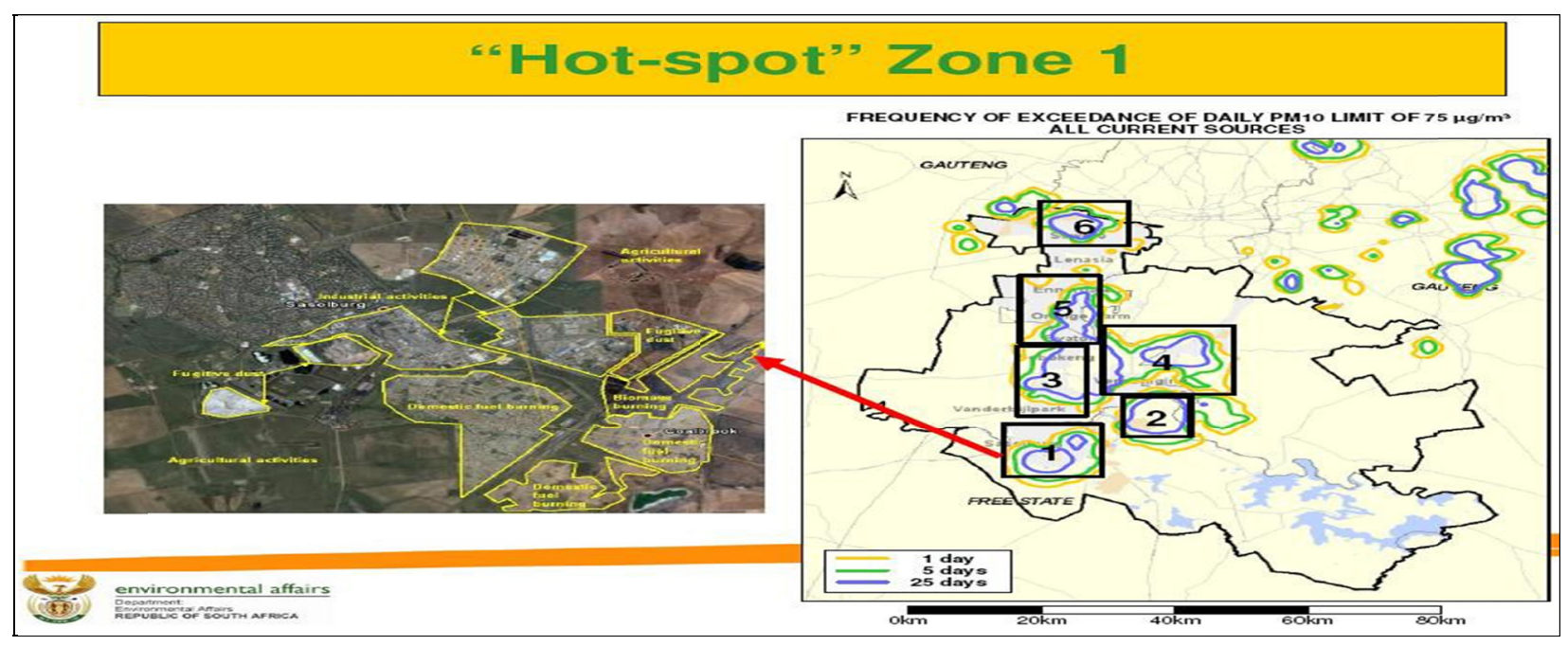

Figure 1. Sasolburg area identified as a "Hot spot" area; Department of Environmental Affairs (2010)

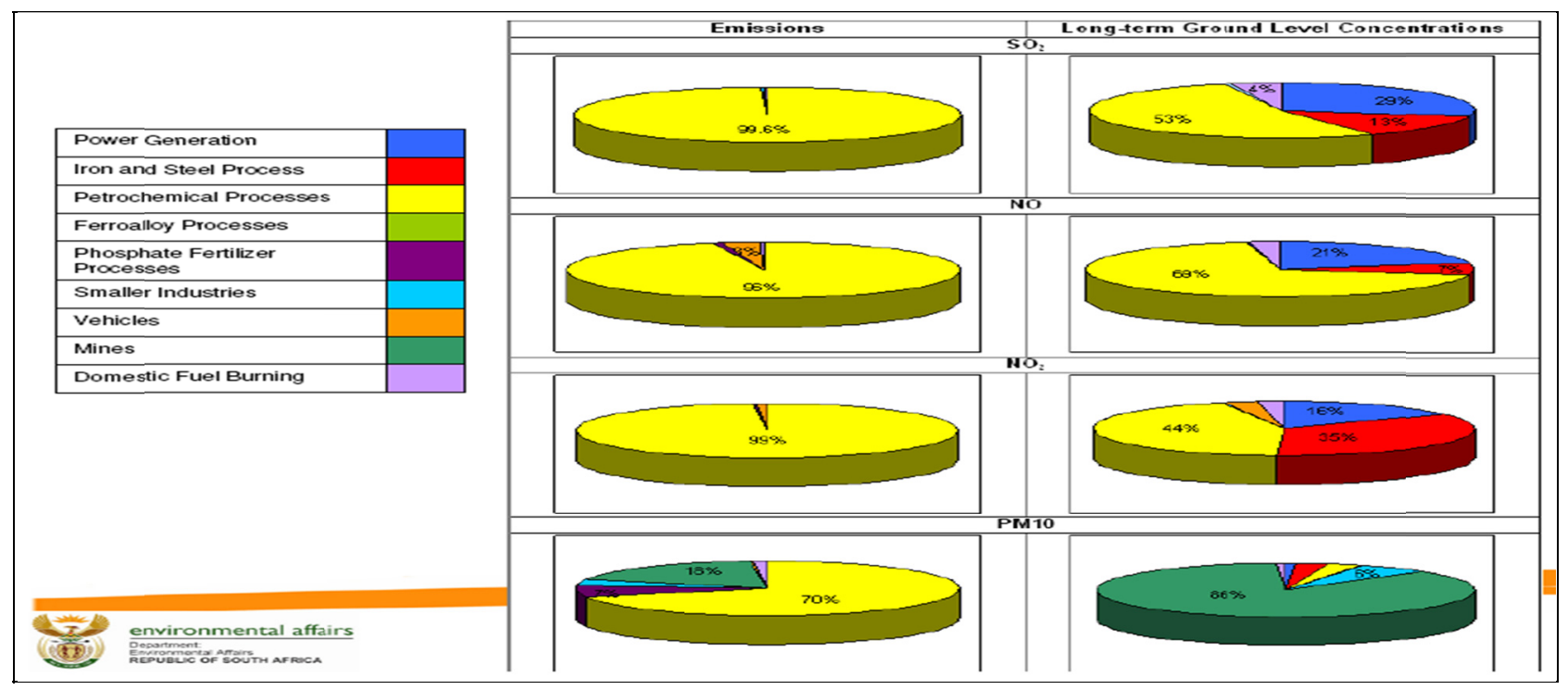

Figure 2. Emissions and long term ground level concentrations of different sources of air pollution in Sasolburg area; DEA (2010) 
Maize is the staple crop in South Africa and widely grown for both commercial and subsistence purposes. South Africa is also the biggest maize producers in Southern Africa. It should also be noted that maize is not particularly sensitive to ozone but some studies has shown relative decreasing yield parameters with exposure to high ozone concentrations (Mulchi et al., 1995; Rudorff et al., 1996). The Free State province contributed 40\% of South Africa's maize production in 2009-2010 and therefore is the province with the highest maize production in South Africa (Department of Agriculture, 2012). Residents of Koppies have indicated that the pollution fumes of Sasolburg can sometimes be smelled, depending on the direction of the wind. Since Koppies is between 60 and $70 \mathrm{~km}$ from Sasolburg, there is evidence to suggest that the greater part of Northern Free State can be influenced by the pollution in Sasolburg.

It is therefore evident that maize production in and around the Sasolburg region can be affected by the pollution where the influence will be directly related to the travelled distance of the pollution from the source. Therefore, the objectives of this paper are to examine air pollution and air quality in the Sasolburg region; to explore and identify pollutants in the air in the Sasolburg region; to compare maize yield at different distances from the pollution sources (Sasolburg) and to determine if pollution have an impact on maize yield. It is also expected that maize yield near Sasolburg will be less than yield far from Sasolburg if air pollution influence maize production.

\section{Methodology}

This paper used both quantitative and qualitative designs. A questionnaire which included aspects relating to air pollution, farmers livelihoods, climate change and agricultural production was used. Furthermore focus group discussions were conducted after face to face interviews with farmers. Permission to conduct the study, the names of farmers and information was obtained from local agricultural office, silos near Sasolburg and SENWES in Koppies, Klerksdorp and Heilbron. Farmers whom are approximately $25 \mathrm{~km}, 50 \mathrm{~km}, 75 \mathrm{~km}$ and $100 \mathrm{~km}$ from Sasolburg, in all three directions, were identified. Three directions included direction of Parys and Viljoenskroon (PV); direction of Koppies and Kroonstad (KK) and direction of Heilbron and Petrus Steyn (HP) (Figure 3).

Purposive sampling technique was used to select farmers to be interviewed. In order to sufficiently quantify the impact of air pollution on maize production it was essential to obtain several and reliable data points to reach meaningful conclusions. In the case of this study it meant identifying farmers with a track record of consistent maize yields. It was also vital to have different readings at the same distance from Sasolburg in order to easily identify outliers and exclude them from the analysis. Several sources were used and ample time set aside to set up interviews to be sure that maximum amount of farmers was visited in the shortest amount of time. Time was also spent on investigating the effect of air pollutants on maize plants and the presence of them in the Sasolburg region. This was done by investigating previous research done and subsequently conducting interviews with environmental specialists at Sasolburg, Heilbron and Kroonstad. The intention was to identify the maize production in different directions away from Sasolburg and to confirm whether the effect of air pollution from Sasolburg does in fact impact the productivity of maize production.

Thus, four sampling points of $25 \mathrm{~km}$ each from Sasolburg were identified in three directions. The data was drawn into Microsoft Excel spreadsheets and plotted on graphs. Data was compared and outliers identified. Additional resources were used to gather other information such as soil analysis and air pollutants in the areas. Data at the closest point from Sasolburg was compared with the data gathered further away from Sasolburg to establish if pollution in the Sasolburg region influences the production of maize.

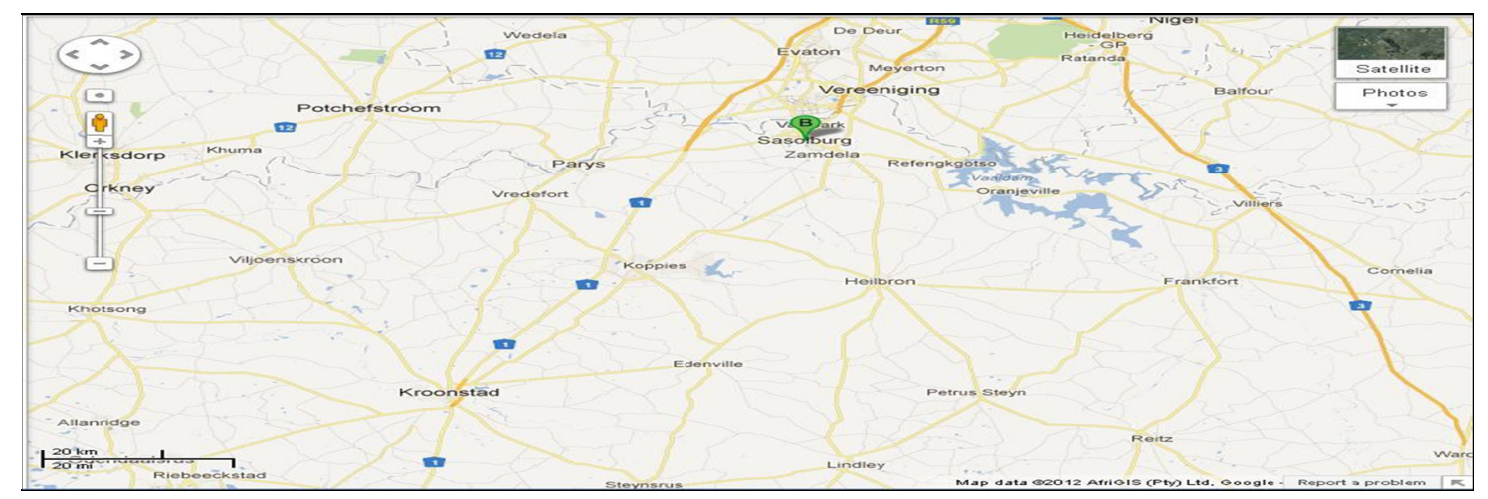

Figure 3. Map of Study area; StatsSA (2011) 


\section{Results and Discussion}

According to a soil study in and around Sasolburg, where industrial, low income residential and agricultural samples were analyzed for persistent organic pollutants, the greatest pollution concentrations in soil occur at the Sasolburg industrial site closest to the source of pollution, followed by the Sasolburg low income residential area (Nieuwoudt et al., 2009). The least pollution concentrations were found in the agricultural soils furthest away from the pollution source (Table 1). Compared to the samples taken at an undisturbed area, indicated as 'Normalized', the concentrations pollutants is much higher in the Sasolburg area. This indicated that the soil in the Sasolburg industrial area and in the Low income residential areas is highly contaminated with undesirable pollutants. Since the Agricultural soil samples also indicate that the soil is contaminated by air pollution, it has to have an effect on the maize production in the surrounding Sasolburg area.

Table 1. Site- and sample specific information for soil samples collected from the Sasolburg region, indicating different pollutants in the soil (Nieuwoudt et al., 2009)

\begin{tabular}{|c|c|c|c|c|c|c|}
\hline & \multirow[b]{2}{*}{$\begin{array}{l}\text { OXC } \\
(\%)\end{array}$} & \multirow[b]{2}{*}{$\begin{array}{l}\text { TOC } \\
(\%)\end{array}$} & \multicolumn{2}{|c|}{ Bio-essay results } & \multicolumn{2}{|c|}{ GC-HRMS results } \\
\hline & & & $\begin{array}{l}\text { TCDD } \\
\text { EQ20 } \\
\left(\mathrm{ng} \mathrm{kg}{ }^{-1},\right. \\
\text { dw) }\end{array}$ & $\begin{array}{l}\text { Normal } \\
\text { TCDD EQ20 } \\
\text { (ng } \mathrm{kg}^{-1} \text {, } \\
\text { dw) }\end{array}$ & $\begin{array}{l}\text { Total } \\
\text { WHO2005-TEQ } \\
\left(\mathrm{ng} \mathrm{kg}^{-1}, \mathrm{dw}\right)\end{array}$ & $\begin{array}{l}\text { Normalized } \\
\text { WHO2005-TE } \\
\left(\mathrm{ng} \mathrm{kg}^{-1}, \mathrm{dw}\right)\end{array}$ \\
\hline Sasolburg Industrial & 3.7 & 4.9 & 2.5 & 5.1 & 6.3 & 1.3 \\
\hline $\begin{array}{l}\text { Sasolburg Low } \\
\text { Income Residential }\end{array}$ & 1.7 & 2.4 & 16 & 6.7 & 1.5 & 0.16 \\
\hline Sasolburg Agricultural & 2.2 & 3.1 & 4.9 & 1.6 & & \\
\hline $\begin{array}{l}\text { Sasolburg: } \\
\text { Taaibosspruit }\end{array}$ & 0.55 & 1 & 0.82 & 0.8 & 0.2 & 0.19 \\
\hline
\end{tabular}

As seen in Table 2, it is clear that inhalable particle matter is a huge problem in the Sasolburg area. Very high daily averages are measured which exceed South African National Standards (SANS) limits and European Commission (EC) limitations. Sulphur dioxide is triple the SANS standards in a calculated 10 minute average and also exceeds the highest hourly average. It is clear that Nitrogen dioxide emissions do not contribute as much to the pollution problem as sulphur dioxide and particle matter, since it complies with most of the emission standards.

Table 2. Predicted Maximum air pollutants due to all activities within Sasolburg (Thomas, 2008)

\begin{tabular}{|c|c|c|c|c|c|c|}
\hline 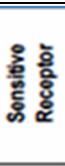 & Pollutant & Averaging period & $\begin{array}{c}\text { Predicted } \\
\text { Maximum } \\
\text { Concentrations } \\
\left(\mu g^{\prime} \mathbf{m}^{\prime} \mathbf{y} \text { No. of }\right. \\
\text { exceedances }\end{array}$ & $\begin{array}{l}\text { Current SA } \\
\text { Standards } \\
\left(\mu g / m^{\prime}\right)\end{array}$ & $\begin{array}{l}\text { SAMIS Limits } \\
\text { (proposed SA } \\
\text { standards) } \\
\left.\text { ( } \mu g^{\prime} / \mathrm{m}^{\prime}\right) / \\
\text { proposed } \\
\text { frequency of } \\
\text { exceedance }\end{array}$ & $\begin{array}{l}\text { EC Limits } \\
\left(\mu g / m^{\prime}\right) / \\
\text { allowable } \\
\text { frequency of } \\
\text { exceedance }\end{array}$ \\
\hline \multirow{20}{*}{$\begin{array}{l}\text { ㅇํㅇ } \\
\text { 흥 } \\
\text { ऊै }\end{array}$} & \multirow{6}{*}{$\begin{array}{l}\text { Sulphur } \\
\text { Dioxide }\end{array}$} & Calculated 10-minute average & 1545 & 500 & 500 & - \\
\hline & & Highest hourty average ${ }^{2}$ & 1080 & 350 & 350 & 350 \\
\hline & & Highest daily average ${ }^{2}$ & 80 & 125 & 125 & 125 \\
\hline & & Annual average & 18 & 50 & so & so \\
\hline & & Frequency of hourty exceedance of $350 \mathrm{pg} / \mathrm{m}^{3}$ (hoursyear) & 10 & $\cdot$ & $88^{0,44 \pi}, 9^{\circ}$ & 24 \\
\hline & & Frequency of daily exceedance of $125 \mathrm{~d} / \mathrm{m}$ ' (daysyear) & 0 & - & $4^{6} 2^{2} \cdot 1^{n}$ & 3 \\
\hline & \multirow{7}{*}{$\begin{array}{l}\text { Nitrogen } \\
\text { Dioxide }\end{array}$} & Highest hourly average & 280 & 376 & 200 & 200 \\
\hline & & Highest daily average? & 32 & 188 & - & - \\
\hline & & Annual average & 6.5 & 94 & 40 & 40 \\
\hline & & Frequency of hourty exceedance of $376 \mathrm{\mu g} / \mathrm{m}^{3}$ (hoursyear) & 0 & 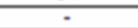 & $\sigma^{0}$ & $\cdot$ \\
\hline & & Frequency of hourty exceedance of $288 \mathrm{hg} / \mathrm{m}^{3}$ (hoursyear) & 0 & - & 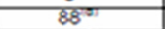 & - \\
\hline & & Frequency of hourty exceedance of $244 \mathrm{~L} / \mathrm{m}$ ' (hoursyear) & 1 & $\cdot$ & $44^{1 /}$ & - \\
\hline & & Frequency of hourty exceedance of $200 \mathrm{\nu g} / \mathrm{m}^{3}$ (hours year) & 2 & - & $9^{\prime \prime}$ & 18 \\
\hline & \multirow{7}{*}{$\begin{array}{l}\text { Inhalable } \\
\text { Particulate } \\
\text { Matter }\end{array}$} & Highest dally average ${ }^{2}$ & 800 & 180 & 75 & so \\
\hline & & Annual average & 200 & 60 & 40 & 40 \\
\hline & & Frequency of dally exceedance of $180 \mathrm{pg} / \mathrm{m}^{3}$ (dayshyear) & 80 & 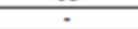 & $0^{0}$ & - \\
\hline & & Frequency of daily exceedance of $127 \mathrm{ug} / \mathrm{m}$ ' (daysyear) & 120 & $\cdot$ & $88^{12}$ & $\cdot$ \\
\hline & & Frequency of daily exceedance of $100 \mathrm{ug} / \mathrm{m}$ ' (dayshyear) & 122 & $\cdot$ & $44^{\circ}$ & $\cdot$ \\
\hline & & Frequency of dally exceedance of 75 ug/m? (dayedyear) & 150 & - & 9 & - \\
\hline & & Frequency of dally exceedance of 50 wo/m' (dayedyear) & 180 & - & - & 35 \\
\hline
\end{tabular}


According to Figure 4 the average maize production in the Free State for 2009 was 4.7 tons/ha and all the farmers in the different direction had a lower maize production than the total Free State average, except for Famers HP3 (4.8 tons/ha) and HP4 (4.9 tons/ha) whose production was higher. In 2010, the average maize production for the province was 4.4 tons/ha and therefore only farmers PV1 (3.7 tons/ha); P V 2 (4.2 tons/ha); KK1 (3.8 tons/ha) and PV3 (4.3 tons/ha) had a lower maize production than the average production of the Free State province. Only farmers PV1 (4.0tons/ha) and HP1 (3.3 tons/ha) had a lower maize production than the average maize production (4.3 tons/ha) of the province in 2011.

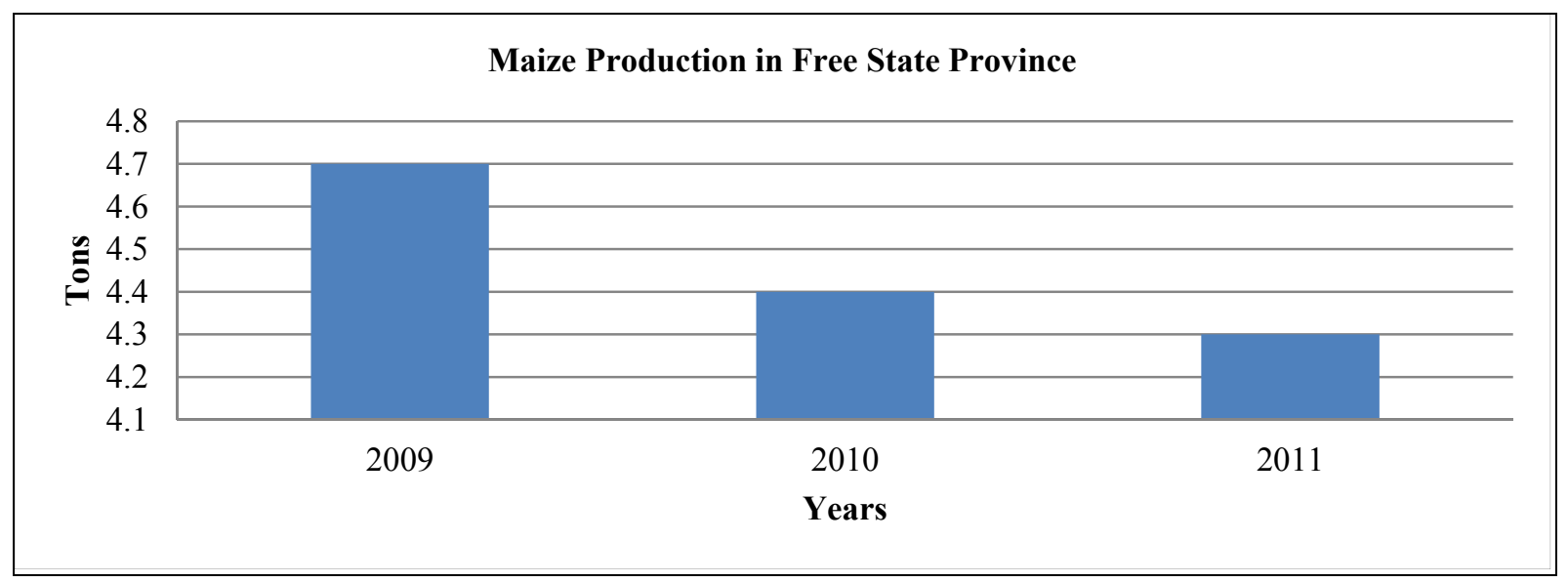

Figure 4. Average Maize Production in Free State Province, Source: Authors

As indicated in Table 3 the average maize production over the past 5 years is increasing with distance from Sasolburg and thus resulting in low yields in maize production near source of pollution. According to Arnold (2012) ozone pollution generated in each of the Northern Hemisphere's major industrialised regions (Europe, North America and South East Asia) has damaged six important agricultural crops (wheat, maize, soybean, cotton, potato and rice) not only locally, but also by travelling many thousands of kilometers. Of the yield losses to Europe caused by ozone, pollution originating from North America is responsible for a 1.2 million ton annual loss of wheat (Arnold 2012). This is the biggest intercontinental ozone-related impact on any food crop and is basically in line with table 3 results. These findings from Arnold ( 2012) also demonstrated that air pollution plays a significant role in reducing global crop productivity and show that the negative impacts of air pollution on crops may have to be addressed at an international level rather than through local air quality policies alone (Arnold, 2012).

Table 3. Farmers Maize Production (Parys and Viljoenskroon Area) Source: Authors

\begin{tabular}{cccccccc}
\hline \multirow{2}{*}{ Farmer } & \multirow{2}{*}{ Distance from Sasolburg $(\mathrm{km})$} & \multicolumn{5}{c}{ Yield per Hectare (tons) } & \multirow{2}{*}{ Average } \\
\cline { 3 - 7 } & & 2007 & 2008 & 2009 & 2010 & 2011 & \\
\hline PV1 & 25 & 3.0 & 3.5 & 3.6 & 3.7 & 4.0 & 3.5 \\
PV2 & 50 & 3.2 & 3.9 & 4.0 & 4.2 & 4.8 & 4.0 \\
PV3 & 75 & 3.9 & 4.0 & 4.2 & 4.3 & 4.9 & 4.3 \\
PV4 & 100 & 4.0 & 4.3 & 4.4 & 6.1 & 5.2 & 4.8 \\
& & \multicolumn{5}{c}{ Total Average of 5 Years } & $\mathbf{4 . 2}$ \\
\hline
\end{tabular}

According to Table 4 the average maize production increases with distance from Sasolburg as results of air pollution. This situation is similar to another study conducted in India by Mukherjee (1999), who emphasised that air pollution is linked to industrial estates in the nearby towns of Ballavgarh and Faridabad and is factory related. The industrial belts of these two towns are close to the villages and smoke and other pollutants from the factories pollutes the air and settle on crops and thus affecting yields. Several studies have also shown that the yield growth rates of some key staple crops have been stagnant or declining 
over the last few decades in many parts of the world as results of air pollution (Tilman et al., 2001; World Bank 2009; Rogerson, 2000). South Africa can therefore benefit directly from these studies with respect to new technology, improved farming methods and equipment, improved maize seeds, improved transport methods.

Table 4. Farmers Maize Production (Koppies and Kroonstad Area) Source: Authors

\begin{tabular}{llllllll}
\hline \multirow{2}{*}{ Farmer } & \multirow{2}{*}{ Distance from Sasolburg $(\mathrm{km})$} & \multicolumn{5}{c}{ Yield per Hectare (tons) } \\
\cline { 3 - 7 } & & 2007 & 2008 & 2009 & 2010 & 2011 & Average \\
\hline KK1 & 25 & 3.2 & 3.0 & 2.6 & 3.8 & 4.3 & 3.3 \\
KK2 & 50 & 3.3 & 3.5 & 3.9 & 4.4 & 5.1 & 4.0 \\
KK3 & 75 & 3.6 & 4.2 & 4.4 & 4.6 & 5.5 & 4.5 \\
KK4 & 100 & 4.1 & 4.4 & 4.6 & 5.1 & 4.9 & 4.6 \\
& & \multicolumn{5}{c}{ Total Average of 5 Years } & 4.1 \\
\hline
\end{tabular}

The data in the Heilbron-Petrus Steyn area corresponds directly with each other (Table 5). It is clear that the farmers closest to Sasolburg (HP1) has 1.4 tons/ha lower maize production than the farmer furthest form Sasolburg (HP4) in the same rainfall region. It is also clear that the farmers furthest from Sasolburg have a higher average maize production over the past 5 years than the farmers closest to Sasolburg. According to Emberson (2012) air pollution impacts on crops has to be taken more seriously as a threat to food security. Air quality should be recognized as a determinant of future crop supply given the sizeable yield losses of staple crops caused by surface ozone, coupled with the challenges facing the ability to be food secure in the coming decades.

Table 5. Farmers Maize Production (Heilbron and Petrus Steyn Area) Source: Authors

\begin{tabular}{llllllll}
\hline \multirow{2}{*}{ Farmer } & \multirow{2}{*}{ Distance from Sasolburg $(\mathrm{km})$} & \multicolumn{5}{c}{ Yield per Hectare (tons) } \\
\cline { 3 - 7 } & & 2007 & 2008 & 2009 & 2010 & 2011 & Average \\
\hline HP1 & 25 & 3.7 & 3.4 & 3.3 & 4.4 & 3.3 & 3.6 \\
HP2 & 50 & 3.9 & 4 & 4.5 & 4.9 & 5 & 4.5 \\
HP3 & 75 & 4.1 & 4.3 & 4.8 & 5.1 & 5.2 & 4.7 \\
HP4 & 100 & 4.6 & 4.7 & 4.9 & 5.2 & 5.6 & 5.0 \\
& & \multicolumn{7}{c}{ Total Average of 5 Years } & $\mathbf{4 . 5}$ \\
\hline
\end{tabular}

\section{Conclusion}

Since the Vaal triangle is classified as a pollution hotspot, and from all the above data which includes the gas submissions by Sasol in Sasolburg, soil analysis by Nieuwoudt et al. (2009), average maize production as well as individual farmers, and other published and unpublished data, it can be concluded that maize production is, in fact, influenced by the air pollution from Sasol and low income residents burning coal and other substances in the Sasolburg region. However, the data also indicates that new technology and techniques make it possible for farmers to maximize maize yield and still, year by year, increase the maize production on their farms. The greatest concern in the coming decades should be the impact of air pollution on food production in the developing countries.

\section{Recommendation}

There is a need, in particular, for an objective assessment to identify the regions and pollutants of greatest concern; improved rural monitoring of pollutant concentrations; evaluation of the pollutant sensitivity of local crops and cultivars; and field experiments to quantify impacts of air pollution. A great contribution could be made to these needs by the governments and scientists of developed countries where impacts of air pollution are of less immediate relevance for the welfare of the population. It is therefore recommended that the problem of pollution in the Sasolburg region is solved, rather than adapting to the circumstances with new agricultural technology. 


\section{References}

Adams, R. M., Glyer, J. D., \& McCarl, B. A. (1988). The NCLAN economic assessment: approaches and findings and implications. In W. W. Heck, O. C. Taylor, \& D. T. Tingey (Eds.), Assessment of Crop Loss from Air Pollutants (p. 473e504). London: Elsevier.

Annegarn, H. J. (1996). Gaseous pollutants. In G. Held et al. (Eds.), Air Pollution and its Impacts on the Southern African Highveld. Cleveland, South Africa: Environmental Scientific Association.

Arnold, S. (2012). Earth and Environment. Air pollution Movement Study, University of Leeds.

DEA. (2012). Department of Environmental Affairs Pollution Report. Retrieved 20 November, 2012, from www.environment.gov.za

Department of Agriculture. (2012). Maize market value chain profile 2010/2011. Department of Agriculture, Forestry and Fisheries.

Embersohn, L. (2012). Food crops damaged by pollution crossing continents. University of York's, Stockholm.

Fuhrer, J., \& Booker, F. (2003). Ecological issues related to ozone: agricultural issues. Environment International, 29, 141-54.

Fumagalli, I. (2001). Evidence of ozone-induced adverse effects on crops in the Mediterranean region. Atmospheric Environment, 35, 2583-87.

Holmes, J. R. (1994). Estimated cost of ozone damage to California crops. Air Resources Board. California Environmental Protection Agency Research Notes, 94.

Kirkman, G. A. (2000). Distribution of aerosols, ozone and carbon monoxide over Southern Africa. South African Journal of Science, 96, 423-31.

Marenco, A., Medale, J. C., \& Prieur, S. (1990). Study of troposphere ozone in the tropical belt (Africa, America) from STRATOZ and TROPOZ campaigns. Atmospheric Environment, $24 A$ (11), 2823-2834.

Mdluli, T. N. (2010). Air Quality Management in South Africa: Application of the Priority Area Management Tool. China: Presentation to the AWMA International Speciality Conference: Leapfrogging Opportunities for Air Quality Improvement.

Mukherjee, N. (1999). Air pollution and crop yields, Global warming and the third world. New Delhi, India.

Mulchi, C. (1995). Morphological responses among crop species to full-season exposures to enhanced concentrations of atmospheric $\mathrm{CO}_{2}$ and $\mathrm{O}_{3}$. Water, Air and Soil Pollution, 85, 1379-1386.

Nieuwoudt, C. (2009). Dioxin-like chemicals in soil and sediment from residential and industrial areas in central South Africa. Chemosphere, 76, 774-83.

Ollerenshaw, J. H., Lyons, T., \& Barnes, J. D. (1999). Impacts of ozone on the growth and yield of field-grown winter oilseed rape. Environmental pollution, 104, 53-59.

Rogerson, C. (2000). Coping with vulnerability in Africa: urban agriculture and poverty alleviation. Africa Insight, 30(3-4), 66-72.

Rorich, R. P., \& Galpin, J. S. (1998). Air quality in the Mpumalanga Highveld region, South Africa. South African Journal of Science, 94, 109-114.

Rudorff, B. F. T. (1996). Effects of enhanced $\mathrm{O}_{3}$ and $\mathrm{CO}_{2}$ enrichment on plant characteristics in wheat and corn. Environmental Pollution, 94(1), 53-60.

StatsSA. (2011). Community survey 2007. Statistics South Africa, Pretoria.

Thomas, R. G. (2008). Air quality baseline assessment for the Vaal airshed in South Africa. Pretoria: University of Pretoria University of Pretoria.

Van Tienhoven, A. M. (2006). Preliminary assessment of risk of ozone impacts to maize (Zea mays) in southern Africa. Environmental Pollution, 140, 220-30.

World Bank. (2009). Policy research working paper 4940 cognitive and behavioral challenges in responding to climate change, Rome.

\section{Copyrights}

Copyright for this article is retained by the author(s), with first publication rights granted to the journal. 
This is an open-access article distributed under the terms and conditions of the Creative Commons Attribution license (http://creativecommons.org/licenses/by/3.0/). 